\title{
Physically Remembering Childhood
}

\section{Stephen J. Smith}

Simon Fraser University

As we walk along the beach I am reminded of similar excursions some 30 years ago. There is the ribbon of coarse sand looping past dilapidated beach cottages where we combed through mounds of seaweed for cuttlefish shells to take home for the budgerigar. I see the trees close to the Point where we discovered "stink bugs," small blackspotted beetles of crimson, orange, and turquoise that left an acrid smell on our fingers. And then there are the chalky-white cliffs standing sentinel above the porous red rocks of that expanse we knew as Scott's Point. At the base of these cliffs we dug for worms in the soft, gluggy clay, playing a kind of tug-o-war with the 20 -inch monsters bedded there.

This afternoon, which seems like so many other afternoons, I am with my two children Shayle and Tyler. We have come with friends, my former schoolmate John and his two sons Michael and Paul. The children, who range in age from three through 10, race ahead, fanning out over the expanse of undulating rock that the receding tide has left exposed. Tyler and Paul call us over to inspect the pool where they have discovered "baby eels" darting into crevices. They touch the sea anenomes whose tendrils tickle their fingers as they withdraw into tight, muscular clumps. They lift the periwinkles from their purchase on the rock walls, turning them over to see the little squirt of water each periwinkle makes as it closes itself to the outside world. Then they bound after Michael to see what he has found in a much larger pool closer to the spray of the ocean.

I watch these children show the same enthusiasm I once had for these rock pool discoveries. I think particularly of that major find, the blueringed octopus. Barely four inches long, and of a dull, dirty grey, it would reveal the most wonderful purplish-blue, iridescent circles. You would touch it when cornered to see these glowing pulses of light. This poor little creature became the quarry on numerous expeditions to Scott's Point, and it was only the subsequent knowledge of its deadly bite that dampened my enthusiasm for playing with it. But now, as I watch the four children inspecting the tidal pools, I harbor a wish that they too will be lucky enough to spot one of these little molluscs.

Around the corner from Scott's Point lies the rusted shell of a small cargo vessel. Long since salvaged, its skeletal remains rest on the sliver

Phenomenology + Pedagogy Volume 101992 
of beach that joins up to Woody Point. To get there one either navigates a course across the exposed rocks or else follows the path that clings to the limestone headland. We decide to take the path on this occasion. "Hang on, I don't think you can get through there anymore," John warns as we approach a section where the cliff has crumbled and left huge boulders blocking the path. We squeeze around them while the children crawl with ease through the openings in between. I carry the youngest, my daughter Shayle, over the next section of the path, because much of it here has fallen away. "Can we get all the way around?" John asks from somewhere behind us. I don't answer. I can already feel the way. Each step reminds me of earlier steps taken. I feel little difference between then and now. Each step brings a familiarity, an intimacy, a physical connectedness to this place.

I let Shayle down to walk the last part of the path onto the beach. I watch her and hear the voices of the children on my heels. Michael, Paul, and Tyler are straining to get past us and explore this new possibility that lies ahead. As they brush past me I am reminded that Scott's Point is not just a place for reminiscence, if indeed it ever could be. It is a place for children, and not just the child I once was, but the children who are now present. The experience of being here again in the company of these particular children makes a difference. Indeed, I am wondering what could draw me back to this place were I all alone. And even if were I to come on this place alone for purposes of reminiscence and nostalgia, it is hard to imagine what meanings it would hold without the reminder of the children's presence. Their presence on this occasion makes all the difference.

The presence of children invariably makes a difference. But what kind of difference might this be? And what difference might feeling their presence make to them? These are questions I want to raise on the strength of the situation described above. By addressing the sort of experience I have just described in which childhood remembrances seem part and parcel of present engagements, I want to understand how a very physical sense of engagement in the present is not just an event to be recalled, but an experience through which the past resonates in physically palpable ways. In particular I want to understand the significance in such experience of being with children and how the presence of children makes such experience profoundly memorable both for them and for me. My hunch is that childhood may be remembered best by being with children and that the most vibrant memories of childhood may be those caught in the immediacy of our present engagement with children. These memories may have as their pedagogic corollary a sympathy for the activity of children and a responsiveness to the course that this activity could most fruitfully take. 
Following this hunch requires from the outset an inversion of how we might ordinarily think of memories of childhood as informing our sense of present activity. Instead of regarding memories as mere recollections, or the residue of past experience, we need to think of those times when being with children creates childhood memories that become clear and distinct only later. In participating with them, we do not "experience a host of impressions accompanied by memories capable of clinching them," nor do we necessarily "see, standing forth ... an immanent significance without which no appeal to memory is possible" (Merleau-Ponty, 1962, p. 22). When actively engaged we feel a physical connectedness that conjoins the personal past and the interpersonal present. We physically remember childhood in our present encounters with children. This notion of memory as a kind of physical mindfulness needs to be seriously entertained (cf. Merleau-Ponty, 1962, p. 181). We need to subvert the intellectualist connotations of remembering by taking heed of phenomenologists like Casey (1987) who writes: "the body as a memorial container - as itself a 'place' of memories-furnishes an unmediated access to the remembered past" (p. 179). We need to see how memories of childhood and the mindfulness that is presupposed are inscribed in the body, the lived body and our physical connectedness to the present.

\section{Physical Memories}

In a previous article on childhood remembrance I alluded to the notion of physical memories (Smith, 1991). I wrote about remembering as a bodily act, giving two well-known illustrative examples of how one remembers physically. The first was from Remembrance of Things Past where Proust (1924) wrote of walking across a courtyard, stumbling on the stones, and in that instant being intoxicated with the feelings of an earlier time. This simple, unintentional movement created a remembering that conscious effort could not perform. The second example, cited in Van den Berg (1961/1975), was of Cocteau's return to the place he grew up. We are told of how Cocteau tries to remember what it was like being there as a child. He runs his hand along a familiar wall, but something is missing. His remembering is more complete only when he thinks to bend down to the level of the child he once was. Immediately it all comes back to him: the smells, the voices, the expressions, the details of childhood experience.

To these examples I now add a third. It comes from The Notebooks of Malte Laurids Brigge in which Rilke (1910/1982) describes the scene he observes while out walking on a pleasant autumn day in Paris. A passerby approaches from the direction of the Champs-Elysées. Rilke notices the man is carrying a crutch. It is not under his armpit, but is held out in front of him "as if it were a herald's staff" ( $p .17$ ). The man pounds the crutch to the ground from time to time, and by the expres- 
sion of mirth on his face seems obviously to be enjoying himself. Rilke writes: "His step was as bashful as a child's, but extraordinarily light, filled with memories of an earlier walking" (p. 18). What this third example gives beyond the previous two is a stronger sense of the physicality of one's capacity to remember. The reminiscence and nostalgia occasioned by stumbling on the stones in a courtyard and by running one's fingers across the surface of a wall seem a little impoverished in comparison with the experience of one whose step is "as bashful as a child's" and who is "filled with the memories of an earlier walking." The stumble is too much of an accident, and bending down is too much of a contrivance. But to walk "filled with memories of an earlier walking" shows the potential of one's memories for giving meaning to present activity.

Rilke's description of a physical memory informs our understanding of walking over the rocks at Scott's Point, for there remains a "presentness" to this experience that is denied when thinking of the body as simply providing "unmediated access to the past" (Casey, 1987, p. 179). Though initially I may close my eyes and turn my back on those around me, I cannot deny the present for too long. The children are an everpresent reminder of that. Though personal memories may inform my actions with these children, it is more the case that being with them summons memories that make present circumstances explicable. Indeed, I want to show them what I can presently see before me. I want to present it to them in a way I know they may not and maybe never will appreciate. Or will they? Perhaps they already know more than I can show them.

\section{Recovering a Childhood}

What will the children remember of this experience? What will the youngest who is not yet four years of age remember of walking around the rocks? We are told that our earliest recollections of childhood do not go much below five years of age. Freud spoke of "childhood" or "infantile amnesia" as a repression of early, and possibly traumatic, experiences. Later psychologists like Schactel and Ulric Neisser stress cognitive discontinuities between early childhood and subsequent experiences. Forgetfulness of early childhood was regarded not so much as the absence of sense-making on the part of infants and young children, but rather the result of not being able to reconstruct this early experience because of the mismatch between its cognitive structure and that of the older child (cf. Ross, 1991, p. 55). Forgetfulness, according to this psychological view, is not then a matter of the insignificance of early childhood experiences, but the inevitable consequence of growing up.

The possible recovery of a sense of these experiences is of a kind alluded to by Proust and Cocteau, and described in detail by MerleauPonty (see Krell, 1990, pp. 93-101). "The forgotten experience is revived 
by the recurrence of a sensation that has left a record, a trace, behind; or it is revived by the understanding and reliving of the bodily attitudes, muscular and vegetative, that the forgotten experience produced" (Schactel, 1959, cited in Ross, 1991, p. 55). One can remember provided one adopts a certain physical posture, feeling the stones underfoot, running one's hands over the contours of the wall, walking the path with the lightness of youth. Such actions reconnect us with the sensations of earliest childhood. And yet it also seems possible to remember events from earliest childhood so graphically that one begins to question the psychological account of forgetfulness.

Autobiographies and memoirs, and especially that genre of autobiographical writing that Coe (1984) calls "The Childhood," provide evidence of the detail with which childhood experience can be recollected. A fine example of such detail comes from Richmond's (1988) account of growing up in Brisbane during the 1940s. Consider, for example, her recollection of events that took place at the kindergarten she attended.

At school children play on swings that sound like magpies calling. Some, established already in small groups, swap cards and marbles while others stand bridging the time between home and school, reluctant and tentative. I eat my lunch at playtime and a teacher chastises me for my stupidity. At twelve o'clock the others have banana sandwiches and drink raspberry cordial from narrow-necked glass bottles. Their sandwiches are wrapped in damp tea-towels. I watch Billy Rudd spill his milk down his grey jumper as he hiccups back sobs that he's been holding in all morning. Milk runs down over his voluminous shorts and sad little frightened legs and mixes with his urine before trickling off diluted down the path. Even my new lunch box fails to cheer me, and the small wrapped sweet my mother has put in it for the first day reminds me too much of home. The day is so long. I watch the big kids. My sister is among them and totally ignores me. They do the strangest things. A row of them makes an archway and others in a line go through. The big kids are singing:

Oranges and lemons,

The Bells of St. Clements,

You owe me three farthings,

When will you pay me,

Today or tomorrow?

Other children stand around picking the surface of the wool off each other's cardigans. They tug and pull and when they have a large palm-full of fuzz they put it in their pockets and go on to someone else with a different colour. (Richmond, 1988, pp. 15-16)

One cannot fail to be impressed with the detail contained in this book of remembrances. But are such details truly remembered? Who is to say that the details have not been provided through intervening experiences? Who is to say that there is not an imaginative reconstruction 
of childhood experience? And even if such a reconstruction of childhhood events were possible, how does this recollective reminiscence through writing bear on the kind of remembering that we are trying to understand?

Krell (1990) also wrote of events from childhood. His reflections on what is at stake in this process of writing and remembering point to an underlying physicality that is not easily discernible in autobiographical writings. He describes it thus:

In order to relax and settle down to sleep I began to write about some of the earliest recollections of childhood, often mere images or vague sentiments devoid of context: my father hoisting me high over his head as I sat on the staircase; or playing by myself under a table with a fire engine; or bringing water to my earliest playmates and heroes, who came each week to collect the trash. My discovery was simply that in writing about these early memory images a vast store of remarkably detailed memories-in fact, an entire world of the most intense perceptions and feelings-began to unfold. I started to trace in the writing of these early memories, at first gropingly, though not without stylistic affectation, a world I assumed had been lost-no, that had indeed been lost, absent, "unconscious," call it what you will. (p. xi, emphasis in original)

Krell tells how later on he spoke to his mother of such events, inquiring whether they really did happen just as he has described them. She confirms the truth of these recollections that he has been able to write down in so much intricate detail, much greater detail than she herself could have provided. But it is not simply this recollective facility that interests Krell. $\mathrm{He}$ is "disturbed by the power of these past presences that, far from being 'haunting,' as they properly ought to have been, were (as Husserl says) leibhaft da, bodily present, in flesh and in blood" (p. xi). His writings give evidence of memories that are not simply imbued with physical sensations, but are more fundamentally of a physical constitution. These memories that are "bodily present, in flesh and in blood," are more potent than nostalgic reminiscences and childhood reveries, more physically connected to who we are than recollections and recognitions, more deeply felt than remembrances and retentions.

Through writing, "the power of these past presences" has been apprehended. I suggest that says something about the importance of writing as a memorial activity, but it also says something about the possible grounds, to which writing points the way, of having memories "bodily present, in flesh and in blood." Certain writings have, in other words, given us a feel for the nature of physically remembering childhood by describing those memories that seem of an inherently physical kind. But this attunement, this intuition, this resonance, is not enough if we want to grasp firmly the significance of situations 
where certain memories inscribe a lived sense of present possibilities involving children. For this we need to divest ourselves further of the sense of bodily detachment to which writings of remembrances and reminiscences often attend.

\section{Physical Traces}

I think at this point of my earlier attempt to define childhood remembrances as a "source" of pedagogical understanding (Smith, 1991). I found the source metaphor appealing because it does not necessarily tie our understanding of present events to a particular time and place; rather, it suggests a continuity of events that inform our experience of the present. There is a fluidity to this metaphor or, as Warnock (1987) puts it, a connotation of "physical continuity between past and present" (p. 51). Still, there remains the implication that our understanding of the present and of the presence of children comes through the remembering that has specific points of reference, focal points, origins even. This implication of the source metaphor, while certainly tenable when one considers the informative power of specific remembrances and recollections, is limiting when one thinks of memories that are "bodily present, in flesh and in blood" and of that remembering that is caught, seemingly without distance, within present physical engagements. Though the mindfulness of this physicality may be traced back to prior experience, to specific situations, events, times, and places, these tracings may disclose, or at least put us on the verge of appreciating, the less detached and more corporeal nature of childhood remembrances. ${ }^{1}$

Krell (1990) gives voice to the concern I have for extricating our thinking about physically remembering childhood from more conventional constructions of memory. He writes about being "on the verge" of a more radical understanding of memory.

To be on the verge is to tend to presence principally in the modes of absence, evanescence, failure to remember, and oblivion....to be on the verge is to be anywhere but at the center or origin of memory, reminiscence, and writing. Nostalgia for that font and source permeates the idealist, empiricist, positivist, and phenomenological projects of philosophy. (p. 166)

Krell sounds a caution in our quest for understanding what the presence of children can mean; indeed, the present inquiry into the grounds for physically remembering childhood may yet be criticized for indulging in a phenomenological nostalgia for a source of pedagogic understanding, and for thus failing to be truly on the verge of understanding what the presence of children can mean. I nevertheless pursue such grounds insofar as I now try to delineate the kind of bodily preparedness required in reaching a point where it could be said that one has acquired the physical capacity to remember childhood in pedagogically sensitive ways. 
My purpose is not so much to map out a way of understanding how one ought to be in the presence of children, as it is to show the means to understanding situations that arise. Such means has to do with the capacity, ability, or state of preparedness that enables us to speak (and write) of the importance of physically remembering childhood. It also has to do with the capacity, ability, or state of preparedness that can be cultivated when speaking (and writing) about remembering. From what has been said so far, physically remembering childhood as a means to understanding what the presence of children requires comes down to the physical bearing of pedagogical thought.

\section{Reminding the Body}

There is a social construction of embodiment that works against the kind of remembering discussed so far. Through analyses inspired largely by Foucault and Bordieu we learn how the body has come to exist as an object for us by virtue of political and economic arrangements that define the form of acceptable physicality (cf. Harvey \& Sparks, 1991). The "physical" body, which is to say, that conception of the body that is sustained by the objective sciences of the body, is but a reflection of the "social" body. What we ordinarily understand as the physical body "is the effect not of a consensus, but of the materiality of power operating on the very bodies of individuals" (Foucault, 1980, p. 55).

There is also a linguistic articulation of the body that tears apart incarnate subjectivity. In the words we use the body is distinguished from the mind, yet undistinguished in its mindlessness. It is my body, your body, and, sadly, a nobody. It is a body to be operated on as a biomedical entity, treated for illness as if it were a physiological organism, and skilled as if it were a machine. Our everyday language creates a forgetfulness of what it might mean to be embodied. Think, for instance, of the voluminous writings that have appeared on the notion of play, much of which has addressed its physiological, biological, and psychological functions at the expense of considering the possibility that play may actually signify a more embodied sense of engagement in the world. ${ }^{2}$ The idea of play has been subjected to an objectification of the body, while the terms of play-children's play, physical play, dramatic play, imaginative play, finger play, foreplayhave served to reinforce this fragmented sense of physicality. Now consider what Ruddick has to say about such linguistic vivisection of play. She writes:

Soon children's bodily lives reveal elaborate, imaginative play. Genitals, limbs, toes, and fingers may acquire distinctive personalities and names. Torsos and faces painted; secret scars and individual oddities as well as "private parts" exposed to gaze and touch; elaborate games of dressing and undressing, making up, masking, and revealing; eating and refusing to eat according to ritual and individual taste; courting and inflicting 
minor pains; building and slimming down; jumping, shouting, singing, cycling - these and many other activities make up children's daily fare. Mothers, in turn, respond to these bodies, cleaning, feeding, soothing, exciting, doting. Neither children nor their mothers could distinguish in their bodily lives between rich elaborate mental play and the "merely physical." (Ruddick, 1989, p. 206)

For Ruddick play signifies a very physical expressivity. Of course it refers to the differentiation of bodily life into activities that we recognize as expressing dimensions of a child's development. More immediately, however, it refers to the recognition that is possible because of the physical resonance that these activities have with adult sensibility. One responds in the first instance to the physical expressivity of children's activity. One responds to that which is most childlike.

For the Greeks, play, paizo, is what a child, pais, does. The Doric form of the verb "to play," paisdo, betrays its origin more clearly than the Attic. Children play with playthings or toys, paignion, or play at a game or sport, paigma, or play an instrument, dance, and sing. What is sung is a paian, a paen to Apollo the Healer, himself called Paian or "physician." Playing, singing and dancing occur during religious celebrations, festivals or healing, paigna. Anything suited to children is described as paideos, whether it be a game, paidia, or their education, paideia or paideusis. A less fortunate accompaniment to education may have been paio to hit or strike! Play, education, music, athletics, and the religious festival, are all bound to the same root-syllable, which sounds the vocative for Greek children: Pai. (Krell, 1972, p. 77)

This etymology gives credence to the suggestion that play alludes to the meaning of being child. Ontologically speaking, "playing brings a fullness to the child's being that is otherwise lacking and forms the fundamental world that will otherwise be taken for granted. In childhood play the fundamental and primordial relation to being is formed and remains rooted" (Vandenberg, 1971, p. 46). Play, "that ontological mode essential to the development of human culture and, even more, to the development of the evolving child" (Suransky, 1982, p. 21) stands out as a term that best characterizes what it means to be a child.

But these are significances that we so easily forget. When talking about play, we attach its meaning to adult games, sports, and recreations, and we transfer its meaning to contexts where "we find talk of the play of light, the play of waves, the play of a component in a bearing-case, even a play on words" (Gadamer, 1984, p. 93). And we forget that play is essentially a term of our relation to children. We think it refers to the activities of various players, some of whom are children; and we forget that it is a term of our physical connectedness to those activities, and through those playful activities in which we can engage, a remembrance of the experience of childhood. Such forgetfulness is not so much an overlooking of the inherent possibilities of play as it is a 
denial of one's physicality. ${ }^{3}$ And to forget one's physicality is at best to allow for a playfulness on the margins of everyday life, and even here to easily disregard play's inherent possibilities.

Physically remembering childhood is fundamentally a matter of reminding the body or being reminded of what its physicality implies. Play is one reminder that stands out, although through talking about and hence configuring play, a bodily forgetfulness can easily occur. So, rather than belabor the possibilities of play, perhaps we should instead talk about what play talk presumes to address. Once again, we should search for the grounds for being reminded of our capacity to physically remember childhood.

\section{A Pedagogical Physique}

Attempts have been made to evoke through language a stronger sense of one's physicality and one's physical connectedness to the world and to others. I mention in passing the thematization of the lived body as it has been developed through the phenomenological movement. Merleau-Ponty, in particular, takes credit for developing the theme of incarnation that he found in the earlier work of Marcel (cf. Kruks, 1987). For him, the body and its lived relations to the world and to others in the world required a language that addressed the "living connection" between body-subject and world (Merleau-Ponty, 1962, pp. 205,208 ) and that moved to a recognition of human relationality as being "in the flesh" (p. 320; cf. Lapointe, 1975). His words evoked a sense of the body as being of the "flesh of the world" (Merleau-Ponty, 1968); however, a felt sense of this embodiment, including a feeling for one's physical connectedness to others, escaped his efforts (in my estimation). More recently Levin's (1985) rescue of the project of embodiment in The Body's Recollection of Being stands out; unfortunately, Levin's metaphorical reference to embodiment tends to float above the grounds for remembering childhood in moments of physical engagement with children, in spite of his expressed attempt to describe "the body of understanding that is implicitly operative in our sensibility-in our feelings, our perceptions, our gestural comportments" (p. 16).

The writings on embodiment of Buytendijk, Van den Berg, and Linschoten also offer hope of an articulation of the physicality of pedagogical understanding. Buytendijk (1950) wrote of the bodily constitution of feelings and emotions; Linschoten (1968) drew partly on the work of James to describe the feelings of corporeality associated with realms of human experience; while Van den Berg (1952-1953) brought attention to "the human body and the significance of human movement." But even with these writers, it is only at their most evocative that they provide a sense of the depth of one's physicality and the physical expressivity of one's relations to others. We can catch but a glimpse of that "secret alliance between animated corporeality and 
spiritual existence... that nowhere is ... so evident as where animated movement becomes the expression of what is most human in human beings: the joy of being in the world" (Buytendijk, 1988) and the joy of remembering what it is like to be a child in the world.

How, then, are we to understand more physically what is inherently a physically remembered relation to children. Perhaps we need to look farther afield, beyond the phenomenological field to writings that evoke a sense of childhood physicality and that implicate us in its sensibility.

\section{The Physicality of Childhood}

Malouf (1975) gives us a memorable example in his recollection of a event from his youth, a memory tinged with slight regret for an opportunity missed. He recalls wandering the streets of Brisbane with his friend Johnno. The two of them spent the afternoon downtown and are making their way home in the early evening when they decide to take a detour down the embankment of the Brisbane river. Malouf writes:

Suddenly, without warning, Johnno had staggered to his feet and was hauling off his shirt.

"What are you doing?" I asked foolishly.

His shirt fell on the boards beside me, his shoes were off, he was slipping his trousers down over his knees.

"I'm going in."

He rolled his socks off and went to the edge of the ramp in his sagging underpants.

"Are you coming?" He stood there, impatient. "Well, are you?"

Silhouetted for a moment against the play of lights on the water, he shivered at the first touch of coldness at his heels, then jack-knifed neatly and was gone.

I was stunned. It had happened so quickly. I got to my feet and peered into the darkness. He was nowhere to be seen. Of course I should call for help, he would probably be drowned. Struck on the head by a tree-trunk or dragged down by the weeds. Only I felt so silly. I stood peering and the river thundered. There was absolutely no sign of him. I cleared my throat, preparing to call. Then about 10 yards offshore, his head appeared, bobbing about in a kaleidoscope of scarlet and green.

"It's great,"'he shouted, waiving a white arm. "Come on in. Piker!" He struck out into midstream, turning skilfully to avoid the debris, and was carried down towards the pylons of the bridge. Then began to swim strongly back again. "Come on in!" he yelled, his voice high against the roaring of the waves. "Piker, Dante! Piker!"

Obviously he was in no danger. I sat with my knees drawn up at the edge of the ramp while he tumbled about in the lights, and began to feel resentful. People up on the bridge had picked him out now. I could see them pointing. Maybe they would call for help, it would serve him right! He was showing off. I sat and sulked. It was too late now to get myself out of my clothes and follow. It would be too deliberate, nothing at all like his free, 
unselfconscious plunge. And besides, I would have to appear in an hour or so at my aunt's house, where the family were at dinner. How could I turn up stinking of riverwater, having dried off on my shirt, and with mud in my hair?

"Piker," Johnno taunted in the darkness.

Sullenly, I waited on the sidelines for him to come out. (pp. 101-103)

In describing the spontaneity of Johnno's actions, Malouf makes an appeal to the physicality of childhood. He and his friend Johnno are admittedly older than children; however, the sense of playfulness, exuberance, spontaneity, and abandon that comes through in the remembering of an earlier time appeals to our childlike inclinations. We imagine sitting on the river bank with Malouf, feeling that same regret he felt as he watches Johnno frolicking in the water.

A similar appeal to the physicality of childhood is made by Hesse (1969) in his pedagogical novel The Glass Bead Game, and once again it involves looking through the physicality of older people to grasp what is childlike. At the end of the novel Hesse writes of a "discovery" that Joseph Knecht makes at the pinnacle of his career as Magister of the Castalian Order and Grand Master of The Glass Bead Game: "that teaching gave me all the more pleasure, the younger and more unspoiled by miseducation the pupils were" (Hesse, 1969, p. 398). Here we learn that Knecht, a man at the height of his intellectual powers ensconced in a position of considerable influence over an Order dedicated to the life of the mind, confesses that "at times my imagination dwelt on matters which in themselves lay outside my functions" (p. 398 ). So he decides to leave the Order to pursue a modest teaching assignment.

Later we witness what Knecht's imagination foretold. We follow him through the mountains to a lakeside cottage where he finally meets his pupil. Knecht wakes early only to find his pupil, Tito, already outside the cottage preparing for a swim. Knecht watches as the boy starts limbering up, his movements appearing to be a dance-like celebration of the sun's first rays. He follows his pupil through the passage of his movements, not simply as a spectator might, but as one who tries to imagine what it might all mean. Hesse goes on to tell us that the teacher himself had a hand in this event.

The boy himself was in the grip of his impulse, without knowing what was happening to him.... Only later would he realize that his dance and his transported state in general were only partly caused by the mountain air, the sun, the dawn, his sense of freedom. They were also a response to the change awaiting him, the new chapter in his young life that had come in the friendly and awe-inspiring form of the Magister. (p. 422).

Knecht's presence has an influence on the boy's activity. Whereas Tito reminds him of things long forgotten, this reminder is partly the 
teacher's doing. The situation unfolds further when Tito presents Knecht with the challenge of swimming across the lake before the sun is fully risen. He dives into the water and has gone some distance before his teacher follows him into the water. Unfortunately, the challenge is too great for Knecht. He disappears beneath the surface, drowning, his body reminded of that physical distance between himself and his pupil. The physicality of childhood is ultimately beyond him.

Both of these examples, Johnno's plunge into the Brisbane river and Knecht's dive into the cold, mountain-fed waters of the lake, resonate with our sense of the physicality of childhood. They describe how the child and, as it has become fashionable to say, the child within, leads the way to rediscovering the possibilities of living in the present. These examples intimate a sensibility that flows back in time without leaving the sensations of the present. What is real is swimming in the Brisbane river and the mountain lake. It is the possibilities of these experiences that engage respectively, Malouf and Johnno, Knecht and Tito. Each is connected through greater and lesser degrees of bodily engagement to the sensuousness and hence the memorability of these lived experiences.

\section{Physical Connectedness}

Memories implicate us more thoughtfully in the present moment than would ordinarily be the case. We could also say that a physical sense of childhood has the same effect. For what makes us most mindful of our bodily connectedness to the world is a feeling of physical continuity between prior experience and present situatedness. Lewis alludes to this connection when describing a situation of being in a park one evening and noticing three small children chasing fireflies. He watches as they stretch their arms out, grasping for these particles of light, only to find them now a few feet away. One child runs to her father, believing she has caught a firefly; but when she opens her hands to show him, nothing is there. "No matter, off she quickly went back to her friends, dizzying themselves in their leaps and hoverings, trying to make out what it must feel like to have such particles of light close to them" (Lewis, 1989, p. 60). Lewis goes on to speak of what these children are experiencing and how sharp a contrast such an experiencing makes with the kind of learning that is cultivated in schools. His question is about the kind of learning that is most worthwhile; however, I take his underlying question to be about how one should remember the importance of children's experience and our connectedness to it. He writes:

Perhaps for clues we have to go back to some of the qualities of our own earliest learnings-to the time, just as with those children chasing fireflies, when our learnings were somehow our hands and feet, indeed the entire experience of our bodies, sensorially probing the world around 
us. We have to find those moments that were never defined as learningbut their meanings are still with us: the time we walked in the snow and listened intently to our footsteps, or the time we fell down in the ocean and couldn't catch our breath. We have to remember that our learning, when we were very young, was not linear - it is learning, as the novelist Eudora Welty noted in One Writer's Beginning, that "stamps you with its moments... It isn't steady. It's a pulse." (Lewis, 1989, p. 62)

For Lewis, the personal past is a reminder of present possibilities.

One does not necessarily need an artistic imagination "to break through this realm of private meanings" (Warnock, 1987, pp. 90-91) and connect with the experiences of children. What is needed is simply a sense of the present wherein one surrenders to a bodily reverie of childhood for the purpose of acting appropriately with children whom we encounter in the here and now. I think of the children's story by Fox (1984) that deals with a small boy called Wilfred Gordon McDonald Partridge who lives beside a home for old people. This little boy knows all the people in the home, but the one he likes to spend time with is Miss Nancy. Unfortunately, Miss Nancy has "lost her memory," or so Wilfred's parents tell him. But Wilfred doesn't know what this means. A memory, his father tells him, "is something you remember." "Something warm, my child, something warm," says Mrs. Jordan. "Something from long ago, me lad," says Mr. Hosking. "Something that makes you cry," "something that makes you laugh," reply Mr. Tippett and Miss Mitchell. "Something as precious as gold," Mr. Drysdale tells him. So Wilfred goes home and gathers up a few keepsakes to take to Miss Nancy. He gives them to her, and with each one-the shoe-box of shells, the puppet, his grandfather's medal, his football, and a hen's egg-she can remember quite vividly some of her childhood events.

This story shows the remembering that is possible for one who at the ripe old age of 96 has supposedly lost her memory. It only takes the presence of a small boy for Miss Nancy to recall a childhood long since forgotten. But Fox has written a story that is not just about the nostalgia of old age. At the end of the story we appreciate that, while Miss Nancy may have lost her memory, her ability to remember childhood was present all along. Remembering remains active. Proof of this comes when Fox narrates: "She bounced the football to Wilfred Gordon and remembered the day she had met him and all the secrets they had told. And the two of them smiled because Miss Nancy's memory had been found again by a small boy, who wasn't very old either." Through these gestures Miss Nancy is still able to "demonstrate the movement of thought through the living body" (Silverman, 1980 , p. 125). "The smile, the relaxed face, gaiety of gesture really have in them the rhythm of action, the mode of being in the world which are joy itself" (Merleau-Ponty, 1962, p. 186). Her gestures attest to a 
remembrance of childhood that is caught within a physical connectedness to the child who stands before her.

A similar physical connectedness is described by Bledsoe (1977-1978). One morning while listening to the radio he hears a news report about a nine-year-old child who has disappeared from his home and who now eight days later is the object of an extensive community search. The plight of this boy has received extensive media coverage, and some have speculated that the boy may actually be in hiding in the tunnels under the city. "People started talking about mysterious clues, missing suitcases, boys taking food down to Simon and warning him when adults got too close. It was reported with all the intrigue and fascination of prowling through unknown and secret places under cover of darkness" (p. 123). What gains Bledsoe's attention, however, is hearing on the radio that day an interview with a child called Billy Sanborn who not only lived in the same apartment block as the missing boy, but who was also somewhat of an expert on the tunnels where the boy was supposed to be hiding. Bledsoe listens as Billy answers the interviewer's questions about the risks being down in the tunnels. But his ears prick up as he hears Billy speak of how he and his friends navigate their way through the tunnel system. Suddenly, writes Bledsoe, "I got a glimpse of an earlier tunnel and a figure of a small boy" ( $p$. 124).

He recalls the fascination a particular concrete storm sewer held for him as a child, until, he says, "one day I decided to crawl inside it and explore it to its source" (p. 121). Bledsoe (1977-1978) gives us a sense of what this experience was like as he describes the cold water that seeped through his pants, the cobwebs that brushed his face, and the sounds of little creatures scurrying off into the darkness ahead. He writes of the hesitation he felt as he responded to the lure of the tunnel: "Some ancient urge beckoned me to go on. Yet there was that clear summons to turn around and go back as well" (p. 121). Eventually he decided to turn around and head back into the light, but not without feeling some regret. Bledsoe writes:

Of course, I made promises to myself after I emerged into the sunlight. I told myself that I would come back with candles and matches, rope and other kids. We'd explore the whole sewer together. We'd learn the inside of that sewer pipe as well as we knew the gully it poured into. I made the promises but I never did go back inside. Promises like that are made but never kept. (p. 121)

It is this broken promise that seems to connect the reminiscence with the radio report of a missing child. In particular, Billy Sanborn's talk of the tunnels indicates how the much earlier promise could be fulfilled. He could share his knowledge with Bledsoe by taking him down into the tunnels. So Bledsoe makes contact with Billy, convincing him and 
his friends to guide him, teach him about what they know of moving through the tunnels. Later Bledsoe reflects on the experience of being down there, learning how to run above the water line, learning how to find his way in the receding darkness, learning about the creatures that inhabit this underworld. He reflects on the physical connectness of this experience.

This exercise of acting out a particular version of childhood experience was in accordance with the laws of my childhood as I remembered them. I participated in the Cave Kids' world in the only way I was equipped to grasp it. That tunnel in Seattle will forever be my reference; however, I tried to put the center of authenticity in the Etobicoke sewers as well. In the nearly 25 years since the first experience, I have finally succeeded in breaking my mind out of its old mould. I recovered a ghost knowledge, one that had never been developed in my mind as a child. It has always existed there, just off to the side somewhere, waiting to be spelled out - to offer its solutions, to help me form intelligent and informed ways of seeing the larger world without ever losing a sense of local vitality. (p. 126)

For Bledsoe the possibilities of the past resonate with the present. The reminiscence of the storm sewer creates interest in a present event; however, it requires an engagement with Billy Sanborn and his friends in tunnel exploration for the significance of past experience to be properly grasped.

Bledsoe (1977-1978) indicates through writing about physically remembering a childhood event what is required of an adult in the presence of children. For it seems that although we can live through children and although we can live with them and show them the manifold possibilities of the present, we can also live alongside them, side by side, and be prepared to be shown the possibilities that lie at hand, within reach, and that keep us in touch with their experiences. Such living requires being fit for the activities at hand. Whether walking about rocks at Scott's Point, diving into a river, swimming in a lake, or some more challenging and possibly risky activity ${ }^{4}$ like exploring a tunnel system, we need to be physically up to what the present demands of us. One needs a physique for going along with children, a stance and posture, but also a pedagogical strength (Evans, 1991) and fitness for staying with them (van Manen, 1991, pp. 122-124). For pedagogy is not in the first instance a reflective affair with children. It is a physical connectedness to those like Johnno, Tito, Wilfred, and Billy who remind us of the possibilities of living fully in the present.

\section{A Childlike Physicality}

Let us bear in mind Erasmus' injunction that the good teacher have sympathy for the child, which involves the physical capacity to engage fully with the child in the task at hand. 
[The good teacher] will also in a sense become a boy again that he may draw his pupil to himself. Though this by no means justifies the choice of the old and infirm as teachers of youth: these indeed have no need to simulate a childish temper, they are only too truly once more in their second infancy. Rather should the master be in the full vigour of early manhood, able to sympathise naturally with youth, ready to adapt himself to its demands. (Woodward, 1964, p. 211).

This claim sounds odd, since one normally expects that experience is the stuff of memories and that age is the memorial container. But a resolution can be achieved if we say that explicit memories are really the residue of our physical being, and that a person who recollects much is really one who is apt to forget who he or she is, and to overlook what he or she is presently doing. One does not need to be young (quite the contrary, as we have seen); however, a youthful disposition seems essential.

This capacity is demonstrated by my friend Sue on a recent visit. On this occasion a number of children are present, two of my own, Tyler and Shayle, Sue's 13-year-old son BJ, and his two friends Simon and Joey. For a good part of the evening the children are out of sight watching a video downstairs and only surfacing now and again for some more pizza, something to drink, or to request potato chips or popsicles because of the occasion. A little later in the evening their presence becomes more apparent. We hear the sounds of scurrying feet, the slamming of doors, and occasional shrieks of surprised laughter. Tyler tiptoes up the internal staircase and peers over the balustrade. "Has BJ come up here?" he asks in a muted voice, scanning the room to ensure that BJ is not lurking in the shadows waiting to pounce. "I need a place to hide," he says in a tone of voice that suggests he is waiting for permission to move into this region of the house.

I am about to admonish Tyler to stay downstairs, thinking immediately of how easily the tranquility of this evening will be disturbed, when I catch an expression on Sue's face that gives me pause for thought. She is giggling as if welcoming the unexpected turn of events. She seems captivated by Tyler's quest for a new hiding place. "You can hide in the hall closet. I don't think he will find you there," she tells him. Sue continues to giggle and tell how marvelous this is as Tyler dashes off to make himself secure in the hallway closet. The other children appear before very long, first Simon, then Joey, with Shayle traipsing along behind. BJ, it seems, has given them a headstart.

As I watch the children take over the living area of the house I am struck by the fact that three 13-year-old boys are playing hide-and-seek with a nine-year-old and a child who is only four years of age. The older ones are not humoring the younger ones; in fact, they seem totally immersed in the game themselves. I am also struck by the fact that 
whereas I had to think about the game's appropriateness, my friend acknowledges it immediately. Her giggling response to Tyler when he ventured up the stairs shows an immediate recognition of what the children are up to and gives tacit approval to their activity. This gesture shows clearly that, far from the situation requiring an earnest response where one might deliberate on the child's request (either allowing the game to spread upstairs or, alternatively, ensuring that the children stay downstairs, and in either case introducing an adult's seriousness into the activity), it requires a response that remembers the joy of playing hide-and-seek. It requires a response from someone who has played this game, perhaps long ago, and who can still feel its movements.

Recollection is not enough; recognition does not suffice; even remembrances of playing hide-and seek may not address the present context. The spirit of the moment requires a remembering that is immediately responsive - an ability to remember that is evidenced first and foremost in the expressivity of the body. In this regard one might speak of remembering as the building of a pedagogical physique. Of course, expressions, silences, gestures, looks, and a host of nonverbal teaching behaviors can be cultivated. But the actions that are most mindful are those like Sue's giggling that remember childhood experience in deeply physical ways and display a gestural openness to the possibilities of present experience.

\section{Blood-remembering}

Rilke (1982) wrote eloquently of the deep physicality of rememberingand of the difficulty of achieving this depth. In doing so, he has pointed to the grounds for much that has been said so far in this exploration of the significance of physically remembering childhood for being with children. For Rilke:

it is not yet enough to have memories. You must be able to forget them when they are many, and you must have the immense patience to wait until they return. For the memories themselves are not important. Only when they have changed into our very blood, into glance and gesture, and are nameless, no longer to be distinguished from ourselves. (p. 20)

I have used the notion of physical remembering up to this point to show that memories are caught in action; however, Rilke takes our thinking a step further by indicating how deeply ingrained such remembering can become. "For Rilke ... the progression is rather from feelings through experiences through memories through forgetting to what can be called, adapting Rilke's own words, blood-remembering" (Mood, 1975 , p. 93). This source of poetic inspiration is the grounds, I suggest, for pedagogic action. 
I try to think at this point of a situation Rilke might approve of. The best I can do is to relate an experience that occurred recently. My son asked if we might cycle down to a local park to search for salamanders, having heard from a grade 6 child at school about seven salamanders he captured by the lagoon at Mundy Park. Tyler wants to find one for himself. Also, Eric and Nicholas, who live a few streets away, express an interest in coming along. So when the boys assemble after school we head off, toting plastic ice cream buckets for the catch.

Never having been salamander hunting before, it is unclear to me where we should begin our search. The boys start lifting rocks and rotted poles at random, sifting through an area of scrub that is holding less and less promise as time goes by. I stay with them, hoping they might get lucky, yet feeling the excitement of this afternoon begin to ebb, much like those fishing expeditions I recall from childhood when expectations of a big catch invariably exceeded the paltry realization. I look over to where the boys have moved and see them talking to a slightly older boy. "This is Ned," Tyler tells me. "He goes to our school. And he's found two salamanders!" Ned proudly displays the contents of his pail.

It turns out that Ned has become something of an expert on these creatures. He knows what they like to eat, how damp their soil should be, how large they grow, and so on. The boys are interested in what he has to say, but they are even more interested in where the salamanders can be found. They follow Ned down the mulch trail to another section of brush, each child filling his pail with moist soil and small twigs in preparation for a major find. "There's two here!" Ned exclaims. He has moved one of the rotting trunks and exposed two greyish-green salamanders nestled together in the compost. He gives the smaller of the two to Eric who shows off his good fortune. The children continue to search with renewed enthusiasm.

Time goes by and I feel compelled to help the boys. I lift a large log and find another couple of salamanders. I call Nicholas and Tyler over to "find" their own. Have I helped them too much? I wonder. Have I intruded before any assistance was requested? Being stronger than they are, it is possible for me to shift the most promising logs; however, I also feel much sympathy for their quest and do not want to detract from their own sense of discovery. And what of my larger responsibilities to these children? I wonder about the ethics of taking salamanders away for pets, to become "my 'pet,' that term of amused contempt for another creature, implying that his or her whole life lies at the mercy of a human hand that can either stroke or strike, feed or withhold food, mold or otherwise shape the creature to that hand's purposes totally independently of what the creature might be or want" (Koller, 1990, p. 97). I think of the possible fate of these salamanders, recalling the fate 
of those blue-ringed octopuses I brought home and that ended up cured in methylated spirits in small glass containers. Still, this kind of responsibility is not one the children can readily assume, even at a time when children are expected to take on all manner of adult responsibility. Nor is it a responsibility that need put a damper on our present undertaking. The excitement and enthusiasm of this expedition needs to be played out. The guidance I want to give takes its cue from Ned's leadership and requires, in the first instance, a mindfulness of what this activity means to Ned and the other children. Like Bledsoe's experience with the cave kids, there is much to be learned from these children. ${ }^{5}$

Eventually the time comes for us to leave. We share a satisfaction as we ride home together. In being with Ned, Tyler, Eric, and Nicholas, I recognize much of myself in their experience. The salamander hunt reminds me of those earlier walks along the beach to Scott's Point, although not in any detailed way. Such a memory seems, as Krell put it, "bodily present, in flesh and in blood." I sense the mood of the earlier time manifested in the present. I am caught in an atmosphere of expectations. I experience through my encounters with the four boys a reverie of childhood that is playing out here and now.

Physically remembering childhood, I have tried to respond to the events as they unfolded. If there were images that guided me, then they are surely contained within an imagination of what the present situation held. ${ }^{6}$ I trust my interventions were filled with memories of an earlier time, nameless and no longer distinguishable from myself. Through glance and gesture I have tried to show the difference between then and now. Through my actions I have tried to cultivate a stronger sense for the children of what their experience could mean. I have tried to make a difference to the quality of these children's experience. This is the difference that my remembering holds for me and this, I hope, is the difference that my physically remembering childhood makes for them.

\section{Notes}

1. Such memories, which can be traced back and forth, could be called "bodily" memories. Yet remembering is always a bodily act of some kind, as evidenced by the fact that some of the most engaging, transporting things we remember are those that are prompted by taste, smell, touch, and by our gestures, expressions, movements, and comportments. All remembering is bodily to a greater or lesser degree, but not all memories are physically engaging. And certainly not all memories are rooted in a physical engagement with children in the here and now.

2. I use the example of play, first of all, because it is a topic that has occupied my attention for some time; second, as someone interested in the physical education of young children, it is a notion that I think needs to be considered; and third and most importantly, in spite of the many connotations of play, its application to experience generally fails to capture the full human significance of that experience. 
3. Etymologically speaking, we deny what lies behind any discernible physicality: what Aristotle called physis to refer to the internal principle of movement that is of the essence of human nature (Peters, 1967, p. 123). Heidegger gave us a feeling for the physis of physicality when he wrote: "Physis, also the arising of something from out of itself is a bringing-forth, poiesis.... For what presences by means of physis has the bursting open belonging to bringing-forth, e.g., the bursting of a blossom into bloom, in itself (Heidegger, 1977, pp. 10, 11).

4. It is interesting to note that risk-taking once referred to navigating among cliffs (cf. Weekley, 1924, p. xii).

5. I am aware of possible criticism from those who would see me juxtaposing pedagogical responsibility and environmental responsibility. But my intent is not to put children's explorations above environmental concern; rather it is to work out in practical ways how care for children's experiences can be contiguous with care for the world in which they live. For although I may more deliberately sensitize them to the objects of their interest by, say, reading with them Mazer's (1991) marvelous story The Salamander Room, my hope is that through my interactions with them in a memorable physical activity a greater environmental sensitivity may be gained on their part.

6. Warnock (1987) concludes, with Sartre, that: "though memory is often thought of in terms of images of the past, and though it is often, in fact, experienced through images, yet it may most properly be thought of as a kind of knowledge, to which images are not an essential, though they may be a frequent accompaniment" (p. 37).

\section{References}

Bledsoe, J. (1977-1978). The world of the cave kid: The rightful recognition of children's knowledge. Interchange, 8(1-2), 119-127.

Buytendijk, F.J.J. (1950). The phenomenological approach to the problem of feelings and emotions. In M.I. Reynolds (Ed.), Feelings and emotions: The Mooseheart symposium (pp. 127-141). New York: McGraw-Hill.

Buytendijk, F.J.J. (1988). The first smile of the child. Phenomenology + Pedagogy, 6, $15-24$

Casey, E. (1987). Remembering: A phenomenological study. Bloomington, IN: Indiana University Press.

Coe, R.N. (1984). When the grass was taller: Autobiography and the experience of childhood. New Haven, CT: Yale University Press.

Evans, R. (1991). Becoming strong: Theorizing as morally oriented. Paper presented to the second International Invitational Pedagogy Conference, University of Utrecht, August 13-15.

Foucault, M. (1980). Power/knowledge: Selected interviews and other writings. Brighton: Harvester Press.

Fox, M. (1984). Wilfred Gordon McDonald Partridge. Adelaide: Omnibus Books.

Gadamer, H.-G. (1984). Truth and method. New York: Crossroad.

Harvey, J., \& R. Sparks (1991). The politics of the body in the context of modernity. Quest, 43(2), 164-189.

Heidegger, M. (1977). The question concerning technology and other essays. New York: Harper and Row.

Hesse, H. (1969). The glass bead game. New York: Holt, Rinehart and Winston.

Koller, A. (1990). The stations of solitude. New York: Bantam Books.

Krell, D.F. (1972). Towards an ontology of play: Eugen Fink's notion of Spiel. Research in Phenomenology, 2, 63-93.

Krell, D.F. (1990). Of memory, reminiscence, and writing: On the verge. Bloomington and Indianapolis: Indiana University Press.

Kruks, S. (1987). Marcel and Merleau-Ponty: Incarnation, situation and the problem of history. Human Studies, 10, 225-245.

Lapointe, F.H. (1975). The evolution of Merleau-Ponty's concept of body. Journal of Phenomenological Psychology, 5(2), 389-404. 
Levin, D. (1985). The body's recollection of being: Phenomenological psychology and the destruction of nihilism. London: Routledge and Kegan Paul.

Lewis, R. (1989). The pulse of learning. Paradola, 14(4), 60-63.

Linschoten, H. (1968). On the way toward a phenomenological psychology: The psychology of William James. Pittsburgh: Duquesne University Press.

Malouf, D. (1975). Johnno. Ringwood, Victoria: Penguin Books.

Mazer, A. (1991). The salamander room (Illustrated by Steve Johnson). New York: Knopf.

Merleau-Ponty, M. (1962). Phenomenology of perception. London: Routledge and Kegan Paul.

Merleau-Ponty, M. (1968). The visible and the invisible. Evanston: Northwestern University Press.

Mood, J.J.L. (1975). Rilke on love and other difficulties: Translations and considerations of Rainer Maria Rilke. New York: Norton.

Peters. F.E. (1967). Greek philosophical terms: A historical lexicon. New York: New York University Press.

Proust, M. (1924). Remembrance of things past. New York: Random House.

Rilke, R.M. (1982). The notebooks of Malte Laurids Brigge (S. Mitchell, Trans). New York: Random House.

Richmond, F. (1988). Remembrance. Sydney: William Collins.

Ross, B.M. (1991). Remembering the personal past: Descriptions of autobiographical memory. New York: Oxford University Press.

Ruddick, S. (1989). Maternal thinking: Toward a politics of peace. Boston, MA: Banyon Books.

Silverman, H.J. (1980). Merleau-Ponty and the interrogation of language. Research in Phenomenology, 10, 123-141.

Smith, S.J. (1991). Remembrances of childhood as a source of pedagogical understanding. Phenomenology + Pedagogy, 9, 158-171.

Suransky, V. (1982) The erosion of childhood. Chicago: University of Chicago Press.

Vandenberg, D. (1971). Being and education: An essay in existential phenomenology. Englewood Cliffs, NJ: Prentice-Hall.

Van den Berg, J. H. (1952-1953). The human body and the significance of human movement. Philosophy and phenomenological research, 13, 90-129.

Van den Berg, J.H. (1961/1975). The changing nature of man. New York: Dell. van Manen, M. (1991). The tact of teaching: The meaning of pedagogical thoughtfulness. Albany, NY: State University of New York Press.

Warnock, M. (1987). Memory. London: Faber and Faber.

Weekley, E. (1924). A concise dictionary of modern English. New York: Dutton.

Woodward, W.H. (1964). Desiderius Erasmus concerning the aim and method of education. New York: Teachers College Press. 